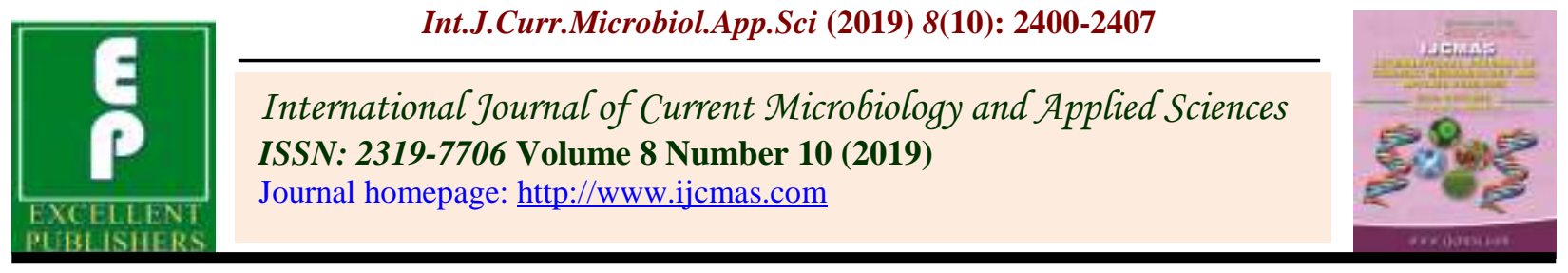

Original Research Article

https://doi.org/10.20546/ijcmas.2019.810.278

\title{
Effect of Integrated Nutrient Management on Vegetative Growth, Flowering and Yield of Papaya (Carica papaya L.) cv. Coorg Honey Dew
}

\author{
B.K. Sethy, D.K. Dash, R.K. Tarai*, S.N. Dash and A.K. Dash \\ College of Horticulture, Chiplima, Orissa University of Agriculture \& Technology, \\ Dist-Sambalpur, Pin-768025, Odisha, India \\ *Corresponding author
}

\begin{tabular}{|l|}
\hline Ke y w o r d s \\
INM, Growth, \\
$\begin{array}{l}\text { Flowering, Yield of } \\
\text { papaya }\end{array}$ \\
\hline Article Info \\
\hline $\begin{array}{l}\text { Accepted: } \\
\text { 17 September } 2019 \\
\text { Available Online: } \\
\text { 10 October } 2019\end{array}$ \\
\hline
\end{tabular}

A B S T R A C T

An experiment was conducted during the year 2015-2016 and 2016-2017 at the experimental plot, College of Agriculture, Chiplima, Odisha University of Agriculture and Technology, Sambalpur, Odisha to find out the effect of integrated use nutrients (organic, inorganic and biofertilizers ) on growth, flowering and yield of papaya cv. Coorg Honey Dew. The maximum plant height $(218.1 \mathrm{~cm}$ and $284.4 \mathrm{~cm})$, stem girth $(41.7 \mathrm{~cm}$ and 62.3 $\mathrm{cm})$, number of functional leaves (46.9 and 51.7), petiole length $(85.7 \mathrm{~cm}$ and $114.9 \mathrm{~cm}$ ) were recorded at 12 and 24 months after planting in papaya plants treated with $100 \%$ RDF + PSB +AZS+AZO i.e. under the treatment $\mathrm{T}_{7}$ which was at par with $\mathrm{T}_{8}$ and significantly superior to untreated control $\left(\mathrm{T}_{10}\right)$ plants. The minimum days required for first flower appearance (148 days), fruit set (166 days) and fruit development (125 days) in papaya was obtained when the plants received with $100 \% \mathrm{RDF}+\mathrm{AZO}+\mathrm{AZS}+\mathrm{PSB}\left(\mathrm{T}_{7}\right)$ as compared to untreated control plants $\left(\mathrm{T}_{10}\right)$ with corresponding values (179 days, 213 days and 155 days) respectively. The cumulative fruit yield was also found highest (55.89 $\mathrm{kg} / \mathrm{plant})$ in $\mathrm{T}_{7}$ which was closely followed by $(53.91 \mathrm{~kg} / \mathrm{plant})$ under treatment $\mathrm{T}_{8}$. The treatments $\mathrm{T}_{7}$ and $\mathrm{T}_{8}$ registered a yield advantage of $234.7 \%$ and $225.7 \%$ over the control $\left(\mathrm{T}_{10}\right)$.

\section{Introduction}

Papaya (Carica papaya) belonging to family Caricaceae, one of the important delicious fruit crop is commercially grown in tropical and sub tropical areas of the world (Yadava et al., 1990). Successful commercial cultivation of improved high yielding varieties of papaya crop depends on critical nutrient management practices due to its continuous growth, flowering and fruiting habit. The response of any crop to added nutrients largely depends on nutrient supplying capacity of soil and crop requirement and is also highly influenced by several ecoadaphic factors and management practices owing to increased cost of fertilizers, their short supply and sustainability issues gaining importance (Hazarika and Ansaris, 2007). The use of chemical fertilizers has resulted in progressive rise in multi nutrient deficiencies, nutrient imbalances, deterioration of soil health and productivity with time. Although, the organic manure contains plant nutrients in small quantities as compared to fertilizers, they influence in building up of organic matter, good soil aggregation, 
permeability of soil and related physical properties to long lasting supply of several macro and micronutrients, vital plant promoting substance substances apart from increasing the density of microbes in the soil. This helps in maintenance and possible improvement of soil fertility and health for sustaining crop productivity. The nutrition of papaya differ from other fruit crops due to its quick growth, continuous flowering and fruiting habit and heavy production as plant would exhibit sensitiveness to low supply of major and minor nutrients. Considering all these facts, the present investigation was carried out with an objective to find out the effect of combined use of organic, inorganic and biofertilizers on the growth, flowering and yield of papaya cv. Coorg Honey Dew.

\section{Materials and Methods}

The present experiment was carried out at the experimental plot, College of Agriculture, Chiplima, Odisha University of Agriculture and Technology, Sambalpur, Odisha during the year 2015-2016 and 2016-2017 respectively. The experiment was laid out in Randomized Block Design with 10 treatments replicated thrice with 6 plants as units. The recommended fertilizer dose (RDF) @ 200:200:250 g NPK per plant/year, respectively were applied in the form of urea, DAP and murate of potash. The treatments are $\mathrm{T}_{1}$ : Recommended dose of NPK (RDF) i.e. 200:200:250 g/plant/year, $\mathrm{T}_{2:}$ 100\% RDF + PSB (25g/plant), $\mathrm{T}_{3}: \quad 100 \% \quad \mathrm{RDF}+$ Azospirillum (25g/plant), $\mathrm{T}_{4:} \quad 100 \%$ RDF + Azotobactor (25g/plant), $\mathrm{T}_{5:}$ 100\% RDF + PSB (25g/plant)+Azospirillum (25g/plant), $\mathrm{T}_{6}$ : $100 \% \mathrm{RDF}+\mathrm{PSB}$ (25g/plant)+Azotobactor (25g/plant), $\mathrm{T}_{7:}$ 100\% RDF + PSB (25g/plant) + Azospirillum (25g/plant) + Azotobactor (25g/plant), $\mathrm{T}_{8}: 75 \% \mathrm{RDF}+\mathrm{PSB}$ (25g/plant) + Azospirillum (25g/plant) +Azotobactor (25g/plant), $\mathrm{T}_{9:} \quad 50 \% \mathrm{RDF}+\mathrm{PSB}$ (25g/plant)+ Azospirillum (25g/plant)
+ Azotobactor (25g/plant), $\mathrm{T}_{10}$ : without any Fertilisers /bio fertilizers (FYM will be common for all treatments $(10 \mathrm{~kg} /$ plant $)$ except $\left.\mathrm{T}_{10}\right)$. The inorganic fertilizers were applied in 4 split doses i.e. at $1^{\text {st }}, 3^{\text {rd }}, 5^{\text {th }}, 7^{\text {th }}$ month after planting. The pit of $45 \times 45 \times$ $45 \mathrm{~cm}$ were dug at $1.8 \times 1.8 \mathrm{~m}$ spacing and well decomposed FYM @ 10kg/treatment was applied at the time of planting. Biofertilizers are applied at the time of planting after incubation mixed with FYM @ ratio 1:8 at 30 $\%$ moisture for 7 days. The data recorded on different vegetative, flowering and yield parameters were analyzed statistically (Panse and Sukhatme, 1995).

\section{Results and Discussion}

From the data presented in the Table 1, it is obvious that the vegetative growth parameters viz. plant height $(\mathrm{cm})$, stem girth $(\mathrm{cm})$, number of functional leaves, leaf area, petiole length, petiole girth etc. varied significantly due to combined use of organic manures, inorganic fertilizers and biofertilizers. The plant height was found to be increased significantly in treatment $\mathrm{T}_{7}(218.1 \mathrm{~cm}$ and $284.4 \mathrm{~cm}$ at 12 and 24 months after planting respectively) i.e. with $(100 \% \mathrm{RDF}+\mathrm{PSB}$ $+\mathrm{AZS}+\mathrm{AZO})$. The shortest plant was obtained in control plants i.e. $\mathrm{T}_{10}(144.4 \mathrm{~cm} \& 195.7 \mathrm{~cm}$ at 12 and 24 months after planting respectively). The tallest plant obtained in $T_{7}$ might be due to combined use of chemical fertilizers, organic manures and biofertilizers. Similar pattern was recorded with respect to stem girth $(41.7 \mathrm{~cm}$ and $62.3 \mathrm{~cm}$ during 12 MAP and $24 \mathrm{MAP}$ ), number of functional leaves (46.9 during $12 \mathrm{MAP}$ and 51.7 at 24 MAP) which were recorded maximum with the treatment $T_{7}$. Lowest stem girth $(19.7 \mathrm{~cm}$ and $31.2 \mathrm{~cm}$ ) and number of functional leaves $(28.8 \mathrm{~cm}$ and $31.6 \mathrm{~cm})$ were recorded from Control plants $\left(\mathrm{T}_{10}\right)$ during 12 and 24 months after planting respectively. The maximum plant height and stem girth obtained in $\mathrm{T}_{7}$ and 
$\mathrm{T}_{8}$ might be due to better utilization of nutrients within the plant as well as translocation of maximum nitrogen to the top. The average leaf area $\left(1883 \mathrm{~cm}^{2}\right)$ was recorded maximum in treatment $\mathrm{T}_{6}(100 \%$ $\mathrm{RDF}+\mathrm{PSB}+\mathrm{AZO})$ closely followed by (1874 $\left.\mathrm{cm}^{2}\right)$ in treatment $\mathrm{T}_{7}(100 \% \mathrm{RDF}+\mathrm{PSB}$ $+\mathrm{AZS}+\mathrm{AZO})$ at 12 MAP. However, it was found highest in treatment $T_{4}\left(1713 \mathrm{~cm}^{2}\right)$ at 24 MAP. Lowest average leaf area was recorded in control plants $\left(1618 \mathrm{~cm}^{2}\right.$ and $\left.1480 \mathrm{~cm}^{2}\right)$ during 12 and 24 months after planting respectively. Petiole length was recorded highest $(85.7 \mathrm{~cm}$ and $114.9 \mathrm{~cm})$ in $\mathrm{T}_{7}$ both during 12 MAP and 24 MAP respectively. Chemical fertilizers which provide nutrients in right amount and proportion at right time accelerate the growth. It is known that nitrogen is essential for cell division and cell enlargement which increased the protoplasm.

The application of biofertilizers like Azotobacter, Azospirillum and PSB increased the availability of nitrogen in soil and also their availability to the plant which reflected higher plant growth. Beneficial effect of applied nutrients in promoting growth was also noted by Tarai and Ghosh (2006) in sweet orange. Organic manures are known to promote microbial population and their activity in the soil that may help to decompose and mobilize the nutrients in available forms (Mustaffa et al., 2002).

Similarly, application of biofertilizers along with FYM created feasible condition for enhanced activity and build up of microbes. Biofertilizers like Azotobacter and Azospirillum fixes the atmospheric nitrogen and PSB solublize the phosphorous content and help in making it available to the plant. The Azotobacter and Azospirillum in addition to $\mathrm{N}_{2}$ fixation might secrete growth promoting substrates like gibberlic acid, indol acetic acid and cytokinins etc which influence root growth. Their proliferation and enhanced cation exchange capacity (Pattanayak et al., 2008) for nutrient absorption might result higher plant growth in papaya. Organic manures along with biofertilizers also improve aeration in the soil which ultimately improved the physiological activities inside the plant like plant height, plant girth, number of leaves and petiole size. The results are in close proximity with the findings of Sharma et al. (2003) in pomegranate, Ghosh and Tarai (2007) in papaya, Mahendra et al. (2009) in Ber and Tandel et al. (2014) in Papaya. Lowest petiole length was obtained in control plants i.e. $\mathrm{T}_{10}(70.0 \mathrm{~cm}$ and $93.0 \mathrm{~cm})$ during $12 \mathrm{MAP}$ and $24 \mathrm{MAP}$. Petiole girth was found maximum $(8.80 \mathrm{~cm})$ in $\mathrm{T}_{6}(100 \% \mathrm{RDF}+\mathrm{PSB}$ + AZS) closely followed by $(8.66 \mathrm{~cm})$ in $T_{5}$ (100\% RDF + PSB+AZS) at 12 MAP. Lowest petiole girth was recorded in control plants i.e. under treatment $\mathrm{T}_{10}(7.00 \mathrm{~cm}$ and $9.33 \mathrm{~cm}$ during 12 and 24 MAP respectively). The increased petiole length obtained under $\mathrm{T}_{7}$ may be explained from the fact that major as well as minor elements are available at optimum proportion in the soil and assimilation of food materials within the plant.

It is evident from the data presented in the Table 2 that the minimum days required for first flower appearance (148 days), fruit set (166 days) and fruit development (125 days) in papaya was obtained when the plants received with $100 \% \mathrm{RDF}+\mathrm{AZO}+\mathrm{AZS}+\mathrm{PSB}$ $\left(\mathrm{T}_{7}\right)$ as compared to untreated control plants $\left(\mathrm{T}_{10}\right)$ with corresponding values (179 days, 213 days and 155 days respectively). This result was in line with the findings of Srivastava et al. (2014). The earliness in flowering might be due to the production of endogenous metabolites earlier in optimum level enabling earlier flowering as reported by Singh and Varu (2013). The cumulative fruit yield varied significantly by different combinations of organic, inorganic and biofertilizers in papaya (Table 3). 
Table.1 Effect of Integrated Nutrient Management on vegetative growth parameters of Papaya cv. Coorg Honey Dew

\begin{tabular}{|c|c|c|c|c|c|c|c|c|c|c|c|c|}
\hline \multirow[t]{2}{*}{ Treatment } & \multicolumn{2}{|c|}{ Plant height $(\mathrm{cm})$} & \multicolumn{2}{|c|}{ Stem girth $(\mathbf{c m})$} & \multicolumn{2}{|c|}{$\begin{array}{l}\text { Number of } \\
\text { functional leaves }\end{array}$} & \multicolumn{2}{|c|}{$\begin{array}{l}\text { Avg. leaf area } \\
\left(\mathrm{cm}^{2}\right)\end{array}$} & \multicolumn{2}{|c|}{ Petiole length(cm) } & \multicolumn{2}{|c|}{ Petiole girth $(\mathrm{cm})$} \\
\hline & 12MAP & 24МАР & 12МАР & 24MAP & 12MAP & 24MAP & 12MAP & 24MAP & 12МAP & 24МАР & 12MAP & 24MAP \\
\hline $\begin{array}{l}T_{1:} \quad \text { Recommended } \\
\text { dose of NPK }(\text { RDF })\end{array}$ & 172.7 & 248.6 & 32.0 & 55.6 & 36.5 & 42.1 & 1656 & 1503 & 75.3 & 102.6 & 8.06 & 11.00 \\
\hline $\mathrm{T}_{2:} 100 \% \mathrm{RDF}+\mathrm{PSB}$ & 190.5 & 261.6 & 37.8 & 58.5 & 40.8 & 45.8 & 1787 & 1683 & 78.6 & 103.9 & 8.36 & 11.66 \\
\hline $\mathrm{T}_{3:} 100 \% \mathrm{RDF}+A Z S$ & 183.3 & 253.6 & 36.3 & 58.2 & 38.7 & 44.6 & 1698 & 1593 & 79.0 & 107.0 & 8.13 & 12.33 \\
\hline $\mathrm{T}_{4:} 100 \% \mathrm{RDF}+A Z O$ & 189.8 & 255.0 & 37.7 & 57.5 & 41.6 & 46.7 & 1740 & 1713 & 79.7 & 104.7 & 8.43 & 10.33 \\
\hline $\begin{array}{l}\mathrm{T}_{5:} 100 \% \mathrm{RDF}+\mathrm{PSB} \\
+A Z S\end{array}$ & 201.6 & 266.9 & 38.0 & 59.7 & 40.2 & 45.7 & 1799 & 1680 & 80.2 & 107.0 & 8.66 & 12.34 \\
\hline $\begin{array}{l}\mathrm{T}_{6:} \quad 100 \% \\
\text { PSB }+A Z O\end{array}$ & 209.1 & 270.2 & 38.7 & 60.3 & 42.3 & 49.4 & 1883 & 1595 & 82.0 & 110.1 & 8.80 & 11.33 \\
\hline $\begin{array}{l}\mathrm{T}_{7:} \quad 100 \% \mathrm{RDF}+\mathrm{PSB} \\
+A Z S+A Z O\end{array}$ & 218.1 & 284.4 & 41.7 & 62.3 & 46.9 & 51.7 & 1874 & 1650 & 85.7 & 114.9 & 8.43 & 12.00 \\
\hline $\begin{array}{l}\mathrm{T}_{8:}{ }^{75 \%} \mathrm{RDF}+\mathrm{PSB} \\
+A Z \mathrm{~S}+A Z O\end{array}$ & 207.6 & 273.5 & 36.9 & 60.1 & 40.3 & 46.6 & 1813 & 1617 & 85.3 & 111.4 & 8.46 & 10.66 \\
\hline $\begin{array}{l}\mathrm{T}_{9:} \quad \mathbf{5 0 \%} \mathrm{RDF}+\mathrm{PSB} \\
+A Z S+A Z O\end{array}$ & 166.3 & 246.5 & 29.0 & 49.6 & 36.0 & 42.4 & 1722 & 1543 & 81.0 & 108.0 & 8.33 & 10.33 \\
\hline $\begin{array}{l}\mathbf{T}_{\text {10: Control }} \text { (No Fertilisers } \\
\text { /biofertilizers) }\end{array}$ & 144.4 & 195.7 & 19.7 & 31.2 & 28.8 & 31.6 & 1618 & 1480 & 70.0 & 93.0 & 7.00 & 9.33 \\
\hline $\operatorname{SEm}( \pm)$ & 9.77 & 6.05 & 1.10 & 0.99 & 1.58 & 1.57 & 39.20 & 67.13 & 1.78 & 1.84 & 0.44 & 0.67 \\
\hline $\mathrm{CD}(\mathrm{P}=0.05)$ & 29.02 & 17.98 & 3.28 & 2.94 & 4.70 & 4.66 & 116.48 & NS & 5.29 & 5.48 & NS & NS \\
\hline
\end{tabular}

$\mathrm{RDF}=(200: 200: 250 \mathrm{~g} / \mathrm{plant} / \mathrm{year}), \mathrm{MAP}=$ Month After Planting 
Table.2 Effect of Integrated Nutrient Management on flowering behaviour of Papaya cv. Coorg Honey Dew

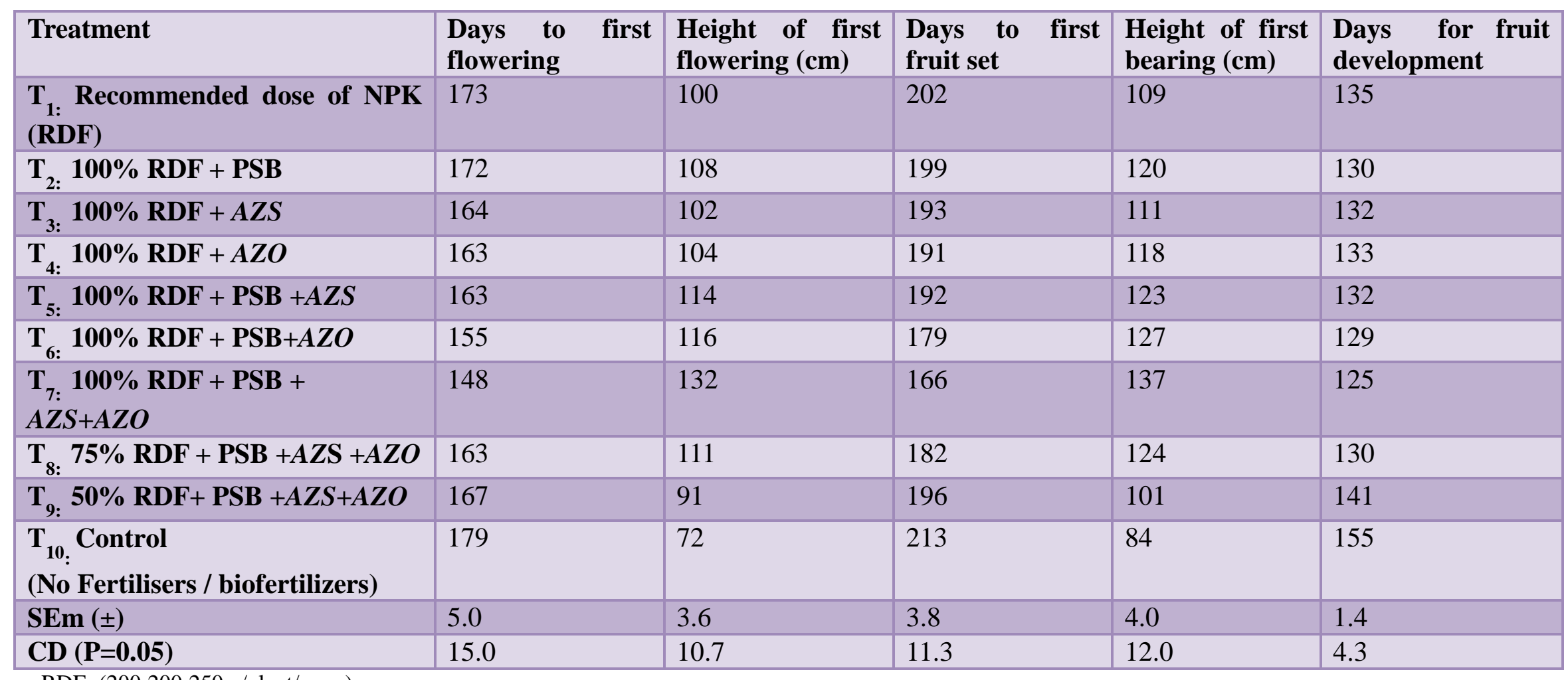

$\mathrm{RDF}=(200: 200: 250 \mathrm{~g} /$ plant/year $)$

$\mathrm{MAP}=$ Month After Planting 
Table.3 Effect of Integrated Nutrient Management on Yield and yield attributing parameters of Papaya cv. Coorg Honey Dew

\begin{tabular}{|c|c|c|c|c|c|c|c|c|c|c|c|}
\hline \multirow[t]{2}{*}{ Treatment } & \multicolumn{3}{|c|}{ Average no. of fruits/plant } & \multicolumn{2}{|c|}{$\begin{array}{l}\text { Average weight } \\
\text { of the fruits(gm) }\end{array}$} & \multicolumn{3}{|c|}{ Average fruit yield (kg/plant) } & \multicolumn{3}{|c|}{ Total fruit yield (ton/ha) } \\
\hline & 12MAP & 24MAP & $\begin{array}{l}\text { Cumulative } \\
\text { Total /plant }\end{array}$ & 12MAP & 24MAP & 12MAP & 24MAP & $\begin{array}{l}\text { Cumulative } \\
\text { Total yield } \\
\text { / plant }\end{array}$ & 12MAP & 24MAP & $\begin{array}{l}\text { CumulativeTotal } \\
\text { Yield }\end{array}$ \\
\hline $\begin{array}{l}T_{1:} \text { Recommended dose of } \\
\text { NPK }(\text { RDF })\end{array}$ & 14.9 & 37.8 & 52.7 & 828 & 748 & 12.33 & 28.27 & 40.61 & 38.1 & 87.3 & 125.3 \\
\hline 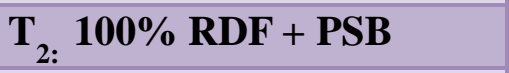 & 15.8 & 39.4 & 55.2 & 837 & 785 & 13.22 & 30.95 & 44.18 & 40.8 & 95.5 & 136.3 \\
\hline $\mathrm{T}_{3:} 100 \% \mathrm{RDF}+A Z S$ & 15.5 & 40.3 & 55.8 & 835 & 793 & 12.94 & 31.94 & 44.88 & 39.9 & 98.6 & 138.5 \\
\hline $\mathrm{T}_{4:} 100 \% \mathrm{RDF}+A Z O$ & 17.1 & 39.1 & 56.2 & 843 & 811 & 14.41 & 31.71 & 46.12 & 44.5 & 97.9 & 142.3 \\
\hline $\begin{array}{l}\mathrm{T}_{5:} 100 \% \text { RDF }+ \text { PSB } \\
+A Z S\end{array}$ & 18.9 & 42.6 & 61.5 & 875 & 861 & 16.53 & 36.68 & 53.22 & 51.0 & 113.2 & 164.2 \\
\hline $\begin{array}{l}\text { T }_{6:} \quad 100 \% \\
\text { PSB }+A Z O\end{array}$ & 17.9 & 43.7 & 61.6 & 894 & 860 & 16.00 & 37.61 & 53.62 & 49.4 & 116.1 & 165.5 \\
\hline $\begin{array}{l}\mathrm{T}_{7:} \quad 100 \% \text { RDF }+ \text { PSB } \\
+A Z S+A Z O\end{array}$ & 19.1 & 44.3 & 63.4 & 896 & 870 & 17.12 & 38.53 & 55.89 & 52.8 & 118.9 & 171.7 \\
\hline $\begin{array}{l}\mathrm{T}_{8:} \quad 75 \% \mathrm{RDF} \quad+\text { PSB } \\
+A Z \mathrm{ZS}+A Z O\end{array}$ & 18.7 & 43.4 & 62.1 & 892 & 863 & 16.64 & 37.47 & 54.11 & 51.4 & 115.6 & 167.1 \\
\hline $\begin{array}{crcc}\text { T }_{9:} & 50 \% & \text { RDF }+ & \text { PSB } \\
+A Z S+A Z O & & \\
\end{array}$ & 13.3 & 33.2 & 46.4 & 792 & 723 & 10.51 & 23.97 & 34.48 & 32.4 & 74.0 & 106.4 \\
\hline $\begin{array}{l}\mathrm{T}_{10} \text { Control (No } \\
\text { Fertilisers /biofertilizers) }\end{array}$ & 10.2 & 22.1 & 32.3 & 602 & 474 & 6.14 & 10.49 & 16.41 & 19.0 & 32.4 & 51.3 \\
\hline $\operatorname{SEm}( \pm)$ & 0.29 & 0.5 & 0.59 & 8.0 & 8.5 & 0.255 & 0.434 & 0.536 & 0.79 & 1.34 & 1.61 \\
\hline $\mathrm{CD}(\mathrm{P}=0.05)$ & 0.86 & 1.4 & 1.77 & 24.0 & 25.0 & 0.759 & 1.290 & 1.591 & 2.34 & 3.98 & 4.79 \\
\hline
\end{tabular}

$\mathrm{RDF}=(200: 200: 250 \mathrm{~g} / \mathrm{plant} /$ year $)$

MAP=Month After Planting 
The number of fruits per plant were recorded highest (19.1 and 44.3 at 12 MAP and 24 MAP respectively) under treatment $\mathrm{T}_{7}(100 \%$ $\mathrm{RDF}+\mathrm{PSB}+\mathrm{AZS}+\mathrm{AZO})$ followed by (18.7 and 43.4 at 12 MAP and 24 MAP respectively) under $\mathrm{T}_{8}$ i.e. with application of $75 \%$ RDF + PSB +AZS+AZO. Lowest number of fruits per plant (10.2 and 22.1 at 12 MAP and 24 MAP respectively) was noticed with control plants $\left(\mathrm{T}_{10}\right)$. Likewise, the fruit weight was recorded highest with treatment $\mathrm{T}_{7}$ (896 $\mathrm{g}$ and $870 \mathrm{~g}$ at 12 and 24 MAP respectively) closely followed by $\mathrm{T}_{8}$. $(892 \mathrm{~g}$ and $863 \mathrm{~g}$ respectively at 12 and 24 MAP respectively). Lowest fruit weight was noticed with control plants (602 $\mathrm{g}$ and $474 \mathrm{~g}$ respectively at 12 and 24 MAP). It was noticed that the number of fruits per plant was recorded lesser up to 12 MAP because of lesser fruiting period irrespective of all the treatments, whereas it was recorded higher from 13 MAP up to 24 MAP due to longer fruiting period. However, heavier fruit was obtained upto 12 MAP due to better vegetative growth of the plant as well free from attack of pest and diseases during initial period of growth. The cumulative fruit yield was recorded highest $(55.89 \mathrm{~kg} / \mathrm{plant})$ under treatment $\mathrm{T}_{7}$ which was closely followed by $(54.11 \mathrm{~kg} /$ plant $)$ under treatment $\mathrm{T}_{8}$. The lowest cumulative fruit yield of 16.41 $\mathrm{kg} /$ plant was recorded in control plants $\left(\mathrm{T}_{10}\right)$. Similarly the highest fruit yield per hectare (171.7 t/ha) was found with the application of $100 \% \mathrm{RDF}+\mathrm{PSB}+\mathrm{AZS}+\mathrm{AZO}$ i.e. under treatment $\mathrm{T}_{7}$ followed by $(167.1 \mathrm{t} / \mathrm{ha})$ in $\mathrm{T}_{8}$ (75\% RDF+PSB+AZS+AZO). The treatments $\mathrm{T}_{7}$ and $\mathrm{T}_{8}$ registered a yield advantage of $234.7 \%$ and $225.7 \%$ over the control $\left(\mathrm{T}_{10}\right)$. The significant response of biofertilizers along with organic and inorganic fertilizers had positively and significantly influenced yield and its attributes. Effectiveness of combined use of organic and inorganic fertilizers in improving the yield may be explained from the fact that organic matter helps to retain urea in the soil (Mistui et al. 1960) and in making the phosphate and potash available to the plants (Roychoudhuri, 1976). It is also well understood that efficiency of biofertilizers can be well exploited when used in combination with organic and inorganic fertilizers (Suther, 2009) which might have improved the yield by better availability and uptake of nutrients by plant roots and enhancing the source: sink relationship by increasing the movement of carbohydrates from the leaves to fruits. The higher dose of nutrients with three biofertilizers increased the availability of nutrients in soil and ensures optimum uptake by plants due to increase in microbial activity in soil, which enhance vegetative characteristics like plant height, stem girth, petiole length etc. that contributes assimilation of more photosynthates within the plant. This result is also in close proximity with the findings of Patil et al., (1995), Singh et al (2013), Ravisankar et al. (2010) and Chaudhri et al. (2001) in Papaya.

\section{References}

Arancon, N.Q., Edwards, C.A. Bierman, P. Welch, C. and Metzger, J.D. 2004. Influences of vermicompost on field strawberries effects on growth and yields. Bioresource Tech. 93: 145-153.

Chaudhri, S.M., Shindhe, S.H., Dahiwalkar, S.D., Danawale, N.J., Shiras, H.K. and Berad, S.M. (2001). Effect of fertigation through drop on productivity of papaya. J.Maharashtra Agric.Univ., 26 (1): 18-20.

Ghosh, S.N. and Tarai, R.K. (2007). Effect of NPK on Yield and quality of Papaya in Laterite soils. Indian J. Fertilizers, 3(5): 47-49.

Hazarika, B.N., and Ansari, S. (2007). Biofertilizers in fruit crops. Agriculture Revie, 28(1): 69-74

Mustaffa, M., Kumar, V., Tanujapriya, B., 
Sivakumar, K. C., and Sathimoorthy, S.,(2002). Organic farming of Karpuravalli. Global Conference on Banana and Plantain,28-31 October, Bangalore. Pp.130.

Panse,V.G. and Sukhatme, P.V. (1995). Statistical methods for agricultural workers, ICAR Publication; New Delhi.

Patil, K.B., Patil, B.B. and Patil, M,T. (1995). Nutritional investigation in papaya var. Washigton. J.Maharashtra Agric.Univ., 20(3): 364-366.

Pattanayak, S.K., Mohanty, S., Mishra, K.N. and Nayak, R.K. (2008). Biofertilizer for tropical vegetables, bulletin published by ICAR.

Ravishankar, H., Karunakaran, G. and Hazarika, S. (2010). Effect of different organic manures with graded levels of inorganic fertilizers on ratoon of Poovan banana. South Indian Hort., 49: 105-108.

Sharma, B.D. Dhandar, D.G. and Bhargava R. (2003). Response of Pomegranate (Punica granatum L.) to integration of nutrient sources in sandy soil of arid ecosystem. In organic farming in horticulture for sustainable production, CISH Lucknow. pp. 33-34.

Singh, J.K and Varu, D. K. (2013). Effect of integrated nutrient management in papaya cv. Madhubindu. Asian J. Hort., 8(2): 667-670.

Srivastava,A., Singh, J.K. and Singh, H.K. (2014). Integrated nutrient management (INM) on growth, yield and quality of papaya (Carica papaya L.) cv. CO-7.

Suther,S.(2009). Impact of vermicompost and composted FYM on growth and yield of garlic (Allium sativum L.) field crops. International J. Plant Prot., 3(1): 27-28.

Tandel,B.M., Patel, B.N. and Patel, B.B. (2014). Effect of Integrated Nutrient Management on growth and physiological parameters of Papaya cv. Taiwan Red Lady. Trends in Biosci., 7(16): 2175-2178.

Tarai, R.K. and Ghosh, S.N. (2006). Integrated nutrient management in Sweet orange cv. Mosambi (Citrus sinensis Osbeck) grown under rainfed condition of laterite soil. The Orissa J. Hort., 34(1): 72-75.

Yadav, P.K., Yadav, A.L., Yadav, A.S. and Yadav, H.C. (2011). Effect of integrated nutrient nourishment on vegetative growth and physic chemical attributes of Papaya. Plant Archive, 11: 327-329.

\section{How to cite this article:}

Sethy, B.K., D.K. Dash, R.K. Tarai, S.N. Dash and Dash, A.K. 2019. Effect of Integrated Nutrient Management on Vegetative Growth, Flowering and Yield of Papaya (Carica papaya L.) cv. Coorg Honey Dew. Int.J.Curr.Microbiol.App.Sci. 8(10): 2400-2407. doi: https://doi.org/10.20546/ijcmas.2019.810.278 